\title{
Formation of segregation structures in Hafnarhraun pāhoehoe lobe, SW Iceland: a window into crystal-melt separation in basaltic magma
}

\author{
Paavo Nikkola ${ }^{1,2}$ (D) $\cdot$ Thorvaldur Thordarson $^{3}$ - O. Tapani Rämö ${ }^{1}$ P Pasi Heikkilä ${ }^{1,4}$
}

Received: 12 March 2019 / Accepted: 16 October 2019 / Published online: 25 November 2019

(C) The Author(s) 2019

\begin{abstract}
To gain insights into crystal-melt separation processes during basalt differentiation, we have studied an 8-m-thick pāhoehoe lava lobe from the Hafnarhraun lava flow field in SW Iceland. The lobe has abundant melt segregations, porous cylindrical and sheet-like structures, generally interpreted as separated residual melts of a lava lobe. We divide these melt segregations into three types based on morphology and composition: vesicle cylinders (VC), type 1 horizontal vesicle sheets (HVS1), and type 2 horizontal vesicle sheets (HVS2). Remarkably, the studied VC are not simple residual melts generated by fractional crystallization, but their composition points to removal of plagioclase from the parental lava. HVS1 resemble $\mathrm{VC}$, but have fractionated more olivine $(\mathrm{ol})+$ plagioclase $(\mathrm{plg}) \pm$ augite and have lost most, if not all, of their olivine phenocrysts. HVS2 are Fe-rich and evolved, corresponding to residual melts after $50-60 \%$ fractional crystallization of the lobe. We suggest that the Hafnarhraun VC formed in a two-stage process. Firstly, VC forming residual melt and vapor detached as rising diapirs from ol+plg+melt+vapor mush near the lava base, and later, these VC diapirs accumulated ol phenocrysts and minor plg microphenocrysts in the lava core. HVS1 represent accumulations of VC to the viscous base of the solidifying upper crust of the lobe, and HVS2 formed as evolved vapor-saturated residual melts seeped into voids within the upper crust. Such vapor-aided differentiation, here documented for the Hafnarhraun lava, may also apply to shallow crustal magma storage zones, contributing to the formation of evolved basalts.
\end{abstract}

Keywords Lava flow $\cdot$ Basalt $\cdot$ Fractional crystallization $\cdot$ Melt segregations $\cdot$ Magmatic differentiation

Editorial responsibility: R.J. Brown

Electronic supplementary material The online version of this article (https://doi.org/10.1007/s00445-019-1330-9) contains supplementary material, which is available to authorized users.

Paavo Nikkola

paavo.nikkola@helsinki.fi

1 Department of Geosciences and Geography, Geology and Geophysics Research Group, University of Helsinki, PO Box 64, FI-00014 Helsinki, Finland

2 Nordic Volcanological Center, Institute of Earth Sciences, Sturlugata 7, 101 Reykjavík, Iceland

3 Faculty of Earth Sciences, University of Iceland, Sturlugata 7, 101 Reykjavík, Iceland

4 Geological Survey of Finland, PO Box 96, FI-02151 Espoo, Finland

\section{Introduction}

Magmatic differentiation by fractional crystallization is one of the key processes of igneous petrology. However, it is not adequately known how crystals separate from their coexisting melts in various magmatic systems. Various mechanisms of crystal-melt separation have been identified. These include gravitational crystal settling (Darwin 1844), liquid convection (Sparks et al. 1984), and filter pressing (Philpotts et al. 1996). It has also been suggested that exsolution of volatiles drives magmatic differentiation in shallow magma storage zones by pressing residual melts out of crystal-melt mushes (Anderson et al. 1984; Sisson and Bacon 1999; Pistone et al. 2015; Parmigiani et al. 2016). In intrusive bodies, the physical processes of crystal-melt separation have proven difficult to study (cf. Wilson 1993), as the emplacement of differentiated magmatic intrusions is often complex and may involve multiple evolutionary stages (e.g., Gibb and Henderson 1992, 2006; Menand 2011). The emplacement mechanism of 
pāhoehoe lavas, however, is well-documented (Self et al. 1998) owing to detailed field observations of effusive eruptions (Hon et al. 1994; Hamilton et al. 2013) and abundant research conducted on solidified pāhoehoe lavas exposed along eroded cliffs, road cuts, and quarry walls (e.g., Walker 1991; Self et al. 1996; Thordarson and Self 1998; Hartley and Thordarson 2009). A well-understood emplacement mechanism, robust control on $\mathrm{P}-\mathrm{T}$ conditions of crystallization, and limited size make pāhoehoe ideal for the study of crystal-melt separation in basalts.

Emplacement of a pāhoehoe sheet lobe can be viewed through a series of steps, outlined herewith (see Hon et al. 1994; Thordarson and Self 1998; Self et al. 1998, for details). When a lobe of hot molten lava breaks out, either directly from the transport system (i.e., lava tube) or from the margins of an existing lobe, its outer surface quenches against the cold surrounding and envelopes the lobe with a viscous and stretchable skin. Given that the newly formed stiff outer layer of the lobe can withstand the pressure of the incoming magma, the lobe starts to grow by continued flow of magma into it. This growth, called lava inflation (Walker 1991), often multiplies the original lobe thickness, so that a lobe initially some decimeters thick can become several meters high (Hon et al. 1994). During inflation, the upper part of the lobe gradually solidifies towards the lobe interior. Due to the internal replenishment in hot magma and efficient insulation provided by the solid upper part of the lobe (cf. Harris and Rowland 2009), the lobe interiors may stay nearly liquid for months to years, thus providing a setting for magmatic differentiation to occur.

Solidified pāhoehoe sheet lobes typically consist of three structural units: basal crust, lava core, and upper crust (e.g., Self et al. 1996; Thordarson and Self 1998; Self et al. 1998). The borders of these units are marked by changes in vesiculation, jointing style, and crystallinity. The basal crust, next to the quenched base of the lobe, usually contains vesicular hypohyaline to hypocrystalline lava, often characterized by elongated, pipe-like vesicles (pipe-vesicle, cf. Walker 1987). The crystallinity of the basal crust gradually increases upwards until the lava transitions to massive, sparsely jointed, macrovesicle poor and holocrystalline lava core (Self et al. 1998). Above the lava core is the upper crust that is generally composed of jointed and highly vesicular (e.g., 20-35 vol\% macrovesicles, Thordarson and Self 1998) lava characterized by repetitive horizontal banding of varying vesicle sizes (Self et al. 1998). The uppermost surface of the upper crust, usually few millimeters in thickness, is the quenched glassy top selvage of pāhoehoe that can exhibit "ropy" surface folding. The critical realization made from these structural units is that the lava core represents the dominantly liquid part, while the upper and basal crusts are the solidifying component of the lobe that grew in thickness during lobe emplacement (e.g., Self et al. 1996; Thordarson and Self 1998; Hartley and
Thordarson 2009). The accretion of upper crust occurs through conductive cooling of the lobe and is continuous throughout the lobe emplacement (Hon et al. 1994), and hence, the upper crust can attain the thickness of several meters. In turn, the basal crust is typically thin $(10-35 \mathrm{~cm})$ irrespective of the height of the upper crust, which has been explained by magma flux-induced thermal-mechanical erosion next to lava base (Thordarson and Self 1998; Hartley and Thordarson 2009).

Besides the primary structural units, many pāhoehoe sheet lobes host melt segregations, which are vesicular (20-40\%) and chemically distinct structures, typically interpreted as separated residual melts of the lava lobe (Anderson et al. 1984; Goff 1996; Rogan et al. 1996; Caroff et al. 2000; Stephenson et al. 2000; Martin and Sigmarsson 2007; Hartley and Thordarson 2009; Sigmarsson et al. 2009; Kuritani et al. 2010). Within the lava core, melt segregations occur as vertical vesicular cylinders, i.e., vesicle cylinders (VC) that often transect the whole lava core from the basal crust to the upper crust (Hartley and Thordarson 2009; Kuritani et al. 2010). In turn, near the top of the lava core and in the upper crust, segregations usually occur as horizontal vesicular sheets, i.e., horizontal vesicle sheets (HVS), and as fillings in large vesicles, i.e., in megavesicles (Thordarson and Self 1998). Melt segregations are typically enriched in incompatible elements relative to the lava surrounding them and thus crystallized from more evolved liquids (Goff 1996; Martin and Sigmarsson 2007; Hartley and Thordarson 2009; Sigmarsson et al. 2009), although VC with more primitive (magnesian) compositions than the host lava have also been reported (Kuritani et al. 2010).

At least three physical models have been suggested to explain the separation of residual melts and formation of $\mathrm{VC}$ in pāhoehoe lavas: vapor differentiation (Goff 1996), RayleighTaylor instability near the base of the lava (Costa et al. 2006), and mushy convection (Fowler et al. 2014). In vapor differentiation, coalescence of bubbles near the partly crystalline base of the lobe results in the formation of proto-cylinders (Manga and Stone 1994). When these proto-cylinders begin to rise, the intercrystalline melt within the partly crystalline basal crust migrates, via gas filter-pressing (Anderson et al. 1984), towards the ascending proto-cylinders (that are regions of low pressure) and $\mathrm{VC}$ are formed. In the Rayleigh-Taylor instability model, $\mathrm{VC}$ are consequential to accumulation of vaporenriched interstitial melt above the crystallizing base of the lava flow from which VC ascend, if sufficiently stiff and buoyant, as diapirs to the liquid lava core due to RayleighTaylor instability (Costa et al. 2006). In the mushy-convection model, VC are consequential to a positive feedback between velocity and permeability in crystallizing lava (Fowler et al. 2014). Gas bubble-growth in partly crystalline lava increases local permeability (increased volume of gas and silicate melt in relation to crystals), which enhances local buoyant upward 
flow (velocity). This, in turn, concentrates evolved intercrystalline melt to the loci of the flow lowering the local liquidus temperature, and as the lower liquidus temperature decreases the rate of crystallization, it enhances permeability and upward flow even further (Fowler et al. 2014). This positive feedback loop may result in VC formation.

Varying models of formation have also been proposed for HVS. Firstly, they have been interpreted as accumulations of $\mathrm{VC}$ at the base of the downward moving cooling front of the lava, which is equal to the base of the upper crust (Goff 1996; Thordarson and Self 1998; Stephenson et al. 2000; Hartley and Thordarson 2009; Sigmarsson et al. 2009). Secondly, they have been understood as interstitial melts that fill subhorizontal fractures in the upper lava flow (Greenough et al. 1999; Kuritani et al. 2010), comparable to the proposed formation mechanism of segregation sheets in intrusions (Marsh 2002). Thirdly, HVS formation in response to the compaction of the lava core (Philpotts et al. 1996) has been suggested.

These varying models of segregation formation imply that (i) the origin and emplacement of melt segregations in pāhoehoe are not adequately understood and (ii) segregation structures are possibly formed via several mechanisms. A quarry in the Hafnarhraun lava flow field, SW Iceland (Fig. 1 ), offers an outstanding site for investigation of segregations, as here a thick (7-8.5 m) pāhoehoe lava lobe that hosts abundant VC and HVS is dissected approximately parallel to its crest by the working face of the quarry. We thus use this site to describe the segregation structures in detail and compile a model of differentiation for this lava lobe. We also discuss the significance of these findings to the improved understanding of related processes of basalt differentiation in crustal magma chambers.

\section{Geological setting}

The neovolcanic rift zones of Iceland are characterized by abundant tholeiitic to olivine tholeiitic basalts erupted from fissure segments, lava shields, shield volcanoes, and stratovolcanoes (Thordarson and Larsen 2007). Pāhoehoe sheet flows

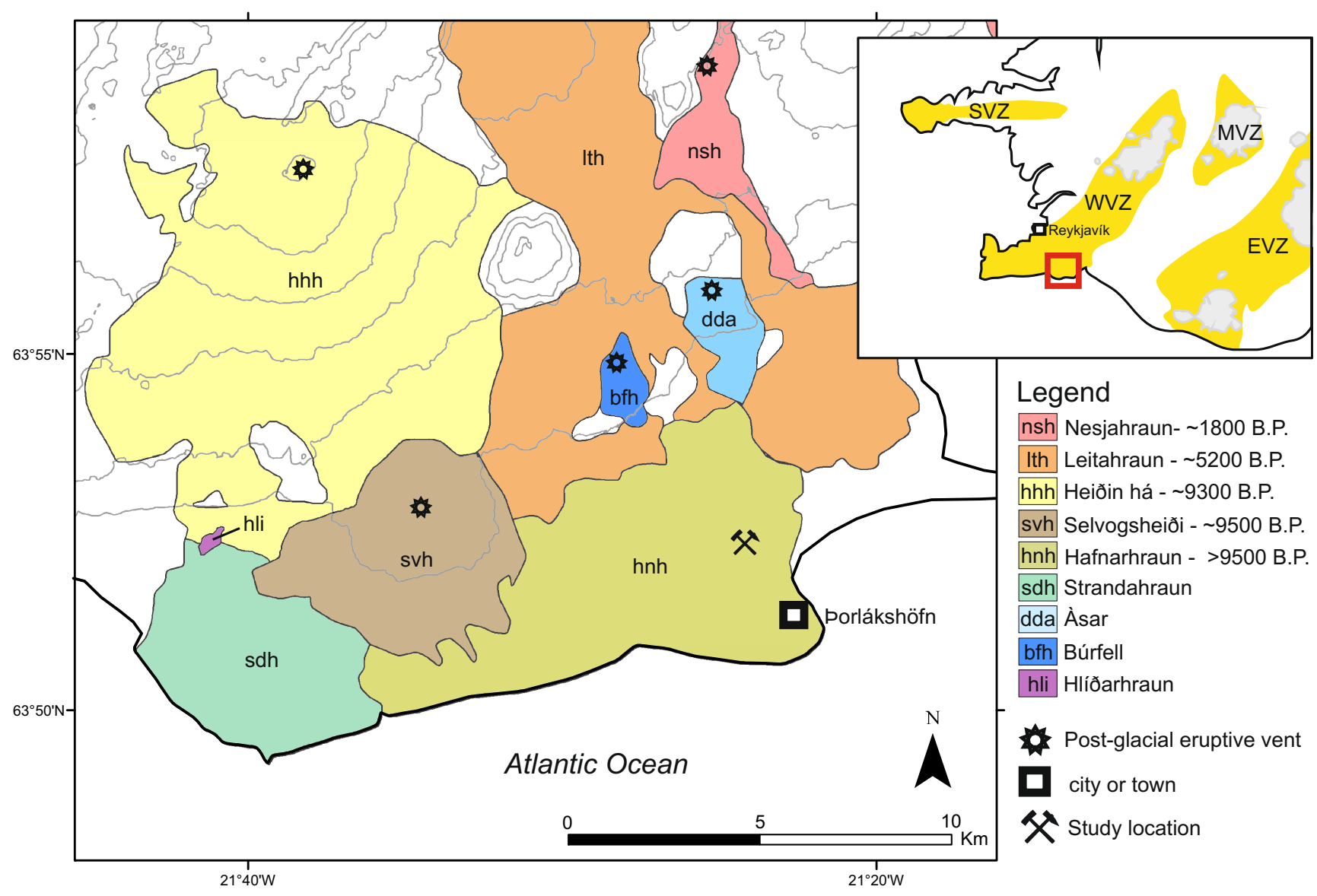

Fig. 1. Geological map of the post-glacial lava units around the Hafnarhraun lava field in SW Iceland with the location of the studied lava lobe marked. Hliðahraun, Búrfell, and Ásar are picritic; the other lava units are olivine tholeiitic basalts. Topographic contours are at $100 \mathrm{~m}$ intervals. Glaciers and currently active volcanic zones of Iceland are shown in inset, SVZ = Snæfellsnes Volcanic Zone, WVZ $=$ Western Volcanic Zone, MVC = Middle Volcanic Zone, and EVZ = Eastern Volcanic Zone. Modified after Sinton et al. (2005), Eason et al. (2015), and Saemundsson et al. (2010) 
are by far the dominant lava morphology but a ā lavas are found as well (e.g., Rossi 1997; Thordarson and Höskuldsson 2008; Pedersen et al. 2017). We investigated the internal structure of pāhoehoe from a quarried lava-rise plateau, topographically elevated by $3-5 \mathrm{~m}$ in comparison with its surroundings, at the Hafnarhraun lava flow field, Western Volcanic Zone of Iceland (Fig. 1). The outcrop segment examined is a 7-8.5-m-high quarry wall that dissects an elongated pāhoehoe lobe approximately along its crest.

The Hafnarhraun lava flow field is composed of pāhoehoe flow lobes with abundant lava tubes and tumuli. Sinton et al. (2005) defined Hafnarhraun as a separate unit from the neighboring Heiðin há and Leitahraun lava flow fields. The exact age of the Hafnarhraun is unknown, although it is clearly postglacial (younger than $\sim 13 \mathrm{ka}$ ) and older than the neighboring Heiðin há lava flow field (Jónsson 1978), for which ${ }^{14} \mathrm{C}$ ages indicate a maximum age around $10.3 \mathrm{ka}$ (Sinton et al. 2005) and ${ }^{3} \mathrm{He}$ exposure age a minimum of $\sim 9.3 \mathrm{ka}$ (Eason et al. 2015).

\section{Materials and methods}

Twenty-three rock samples were analyzed from the exposed section of the Hafnarhraun lava lobe. The sample set includes pieces of the upper crust (5 samples), basal crust (1 sample), VC (2 samples), HVS (9 samples), and lava core (6 samples). The lava core and the quenched top selvage of the lava flow were sampled in abundance to quantify chemical variation in the host lava outside the segregations. Two samples of the extensive lowermost HVS were taken $5 \mathrm{~m}$ apart to evaluate homogeneity of the unit.

The major and trace element composition of the samples was analyzed with PANalytical Axios mAX 4kW WD-XRF from glass beads at the Department of Geosciences and Geography, University of Helsinki. The rock samples were crushed to chips (2-5 $\mathrm{mm}$ in diameter) using an iron-jawed crusher, wet-sieved with deionized water to reach the $1-5 \mathrm{~mm}$ fraction, and fine-powdered with agate-mill. Glass beads were fused using a sample-flux ratio of $1: 10(0.600 \mathrm{~g} \pm 1 \mathrm{mg}$ sample and $6.000 \mathrm{~g} \pm 1 \mathrm{mg}$ Li-borate ultrapure flux: $49.5 \mathrm{wt} \%$ $\mathrm{Li}_{2} \mathrm{~B}_{4} \mathrm{O}_{7}, 49.5 \mathrm{wt} \% \mathrm{LiBO}_{2}$, and $1.0 \mathrm{wt} \% \mathrm{LiBr}$ ). The measurement application in SuperQ 5 software was set up for minimized line-overlap issues (maximum accuracy) and calibrated with 20 basalt to granite natural rock certified reference material (CRM) standards that were prepared identically to the unknown samples. The application contained corrections for background, selected line-overlaps, and a fixed-alpha matrix correction table that was calculated for andesitic composition. A total analysis time of $2.5 \mathrm{~h}$ per sample was used for high precision results. Sample $33 \mathrm{TH} 15$ was repetitively analyzed for 20 times, which revealed standard deviations of $<$ $0.05 \mathrm{wt} \%$ for major oxides (cf. Online Resource 1).
To evaluate the amount of mineral phases and vesicles in various structures within the lava lobe, $1.5 \times$ $2.5 \mathrm{~cm}$ areas in six thin section samples were point counted (600 points in total) with a standard electromechanical point counter ( $\mathrm{cf}$. Table 1). In addition, the composition of rock-forming minerals was determined by using a JEOL JXA-8230 electron microprobe at the University of Iceland. In total, 192 spots were measured from thin sections of four samples (11TH15-G, 11TH15D, 33TH15, and 35TH15), 75 from plagioclase, 52 from olivine, and 65 from clinopyroxene (cf. Online Resource 1). Beam current and acceleration voltage were set at 15 $\mathrm{nA}$ and $15 \mathrm{kV}$, respectively. An electron beam diameter of $5 \mu \mathrm{m}$ was used for plagioclase analyses, and a focused beam when measuring clinopyroxene and olivine compositions. To check for instrumental drift, crystals of known composition were analysed in regular intervals.

To understand the formation of the segregation structures, we modelled the fractional crystallization of the host lava using COMAGMAT-5.2.2. (Ariskin 1999; Ariskin et al. 2018) software that utilizes phase equilibria to calculate phase compositions in mafic silicate melts. All calculations were performed at FMQ (the fayalite-magnetite-quartz buffer), at $1 \mathrm{~atm}$ crystallization conditions, and the model of Kress and Carmichael (1991) was used to calculate the activities of $\mathrm{Fe}^{3+}$ and $\mathrm{Fe}^{2+}$ species in the melt phase. We also utilized Rayleigh fractionation (Rayleigh 1896) of incompatible elements to evaluate the amount of fractional crystallization required in the host lava to generate segregations. According to Rayleigh fractionation, if an element is incompatible to crystallizing phases, its content in residual liquid (CL) is the element content in initial host lava (CH) divided by liquid fraction. Hence, the crystal fraction (FC) at the time of melt separation can be calculated as $\mathrm{FC}=1$ $-(\mathrm{CH} / \mathrm{CL})$.

\section{Hafnarhraun pāhoehoe lobe}

\section{Internal structure}

The exposed internal structure of the lava lobe resembles that of a pāhoehoe sheet lobe, i.e., the basal crust, the lava core, and the upper crust (Fig. 2a) can all be identified, although here the lava crust is unusually thick, approximately $\sim 60 \%$ of the 7-8.5 m lobe thickness. In addition, the exposed lobe hosts abundant VC and HVS melt segregations.

The base of the pāhoehoe lobe, the basal surface, is quenched basaltic glass (tachylite) resting directly on an earlier pāhoehoe lobe (Fig. 2b). The basal crust is $10-20-\mathrm{cm}$ thick and contains an abundance of pipe vesicles (cf. Walker 1987). The pipe vesicles are present in clusters, and they seem to transform to $\mathrm{VC}$ that extend into the lava core above (Figs. 
Table 1 Point counting results, vesicularity and modal mineralogy (vol\%), of units within Hafnarhraun pāhoehoe lobe

\begin{tabular}{lcccccc}
\hline & Lava core & Basal crust & VC & HVS1 & HVS1 & HVS2 \\
\hline Sample ID & 11 TH15-G & 49 TH16 & 11 TH15-D & 31 TH15 & 33 TH15 & 35 TH15 \\
Height (m) & 1.7 & 0 & 1.7 & 3 & 4.55 & 4.1 \\
Porosity (\%) & 12 & 15 & 33 & 30 & 37 & 23 \\
Ol-ph & 11 & 6 & 13 & 5 & 0 & 0 \\
O1 & 8 & 4 & 7 & 5 & 6 & 0 \\
Plg & 43 & 21 & 42 & 46 & 42 & 33 \\
Cpx & 28 & 0 & 31 & 30 & 34 & 33 \\
Oxides & 5 & 0 & 3 & 8 & 9 & 13 \\
Glass & 5 & 69 & 3 & 6 & 9 & 20 \\
\hline
\end{tabular}

${ }^{\text {a }}$ Sample height from the bottom of the lava flow (max $8 \mathrm{~m}$ )

$V C$ vesicle cylinder, HVS1 type 1 horizontal vesicle sheet, HVS 2 type 2 horizontal vesicle sheet, Ol-ph olivine phenocryst, $\mathrm{Ol}$ groundmass olivine, $\mathrm{Plg}$ plagioclase, $\mathrm{Cpx}$ clinopyroxene
$2 \mathrm{~b}$ and S-2 in Online Resource 2). The lava core is approximately 3-m-thick and comprised of massive lava with numerous VC commonly transcending the core (Figs. 2a, b and S-3 in Online Resource 2). At a height of $3 \mathrm{~m}$, the $\mathrm{VC}$ connect to a 4-7-cm-thick HVS with a lateral extent of $\sim 15 \mathrm{~m}$ (Fig. 2a). Above this horizon, we define the boundary between lava core and upper crust (height $=\sim 3.15 \mathrm{~m}$ ), i.e., below this level, the lava was mostly liquid when the input of fresh magma into the lobe came to halt. This is supported by the change in jointing and vesiculation in the lava and by the fact that continuous VC are nonexistent above this level. The lower $3 \mathrm{~m}$ of the lava crust is poorly vesicular, but contains multiple MV and HVS (Figs. 2a and S-4 in Online Resource 2). The top $2 \mathrm{~m}$ of the upper crust, in turn, is highly vesicular, and variations in vesicle sizes define horizontal banding, as common in pāhoehoe (Self et al. 1998). The very top of the lobe is defined by up to 1-cm-thick glassy selvage and often features well-preserved ropy domains. Jointing in the examined lava section is dominantly uneven and blocky, especially in the lava core (Fig. 2a). Systematic vertical jointing becomes less evident with depth in the lobe, being the strongest at the top $2 \mathrm{~m}$ of the flow, and sparse and often curved in the lava core. Maximum horizontal jointing is present in the lower parts of the upper crust (Fig. 2a).

Melt segregations in the lava core and upper crust differ from the host lava by their high vesicularity (2333 vol\%) and darker color (Fig. 2). The boundaries between the host lava and the segregations are sharp (Fig. $2 \mathrm{c}, \mathrm{d})$, whereas the vesicularity in the upper crust has a gradational boundary to the underlying lava. VC are continuous cylindrical structures that extend from the basal crust to the lowermost extensive HVS that is $3 \mathrm{~m}$ above the lava base. In the lowermost $0.7 \mathrm{~m}$ of the lava core, the $\mathrm{VC}$ are inclined in the direction of flow (Fig. 2b). Above this level, they are vertical and their diameter varies relative to their height in the lobe: $1 \mathrm{~cm}$ close to the base of the crust (Fig. 2b) and $\sim 3-4 \mathrm{~cm}$ at $2 \mathrm{~m}$ height (Fig. 2c). VC can locally occupy 10-22\% of the surface of the quarry wall in the lava core, but they are scarce above the lowermost HVS (i.e., above $\sim 3 \mathrm{~m}$ ), with only one discontinuous VC-like bubble trail, which was not sampled, found from the upper crust. In the upper crust, the abundant HVS are at most $3 \mathrm{~m}$ in lateral extent and $35 \mathrm{~cm}$ in height, and they often have a podlike character with thick center and tapered edges (Figs. S-4 and S-5 in Online Resource 2). Unlike the laterally extensive lower-most HVS that is linked to the VC in the lava core, there is no visible connection between HVS in the upper crust and the underlying segregation system at least on the plane of the quarry face.

HVS within the Hafnahraun lava lobe can be divided into two types based on their petrography and whole-rock chemistry: less-evolved type 1 HVS (HVS1) and more-evolved type 2 HVS (HVS2). In outcrop, we could not distinguish these two sheet types from each other, although hand samples of HVS2 are slightly darker due to their finer, often microcrystalline, groundmass (Fig. 3f). The lowermost extensive HVS is of type 1, but otherwise, HVS1 and HVS2 are located randomly in the upper crust. Both can contain overlying megavesicles. In one instance, HVS2 (sample 34TH15-B) was found overlying HVS1 (sample 34TH15-A). We identified these two HVS from each other only during sample preparation due to the darker tone of the overlying HVS2 (Fig. S-6 in Online Resource 2).

\section{Petrography and mineralogy}

Point counting results of mineral phases in the different lithological units are shown in Table 1, and photomicrographs of the respective units are given in Fig. 3. Olivine, plagioclase, and clinopyroxene compositions in the lava lobe are illustrated in Fig. 4 and given in Online Resource 1. 
a

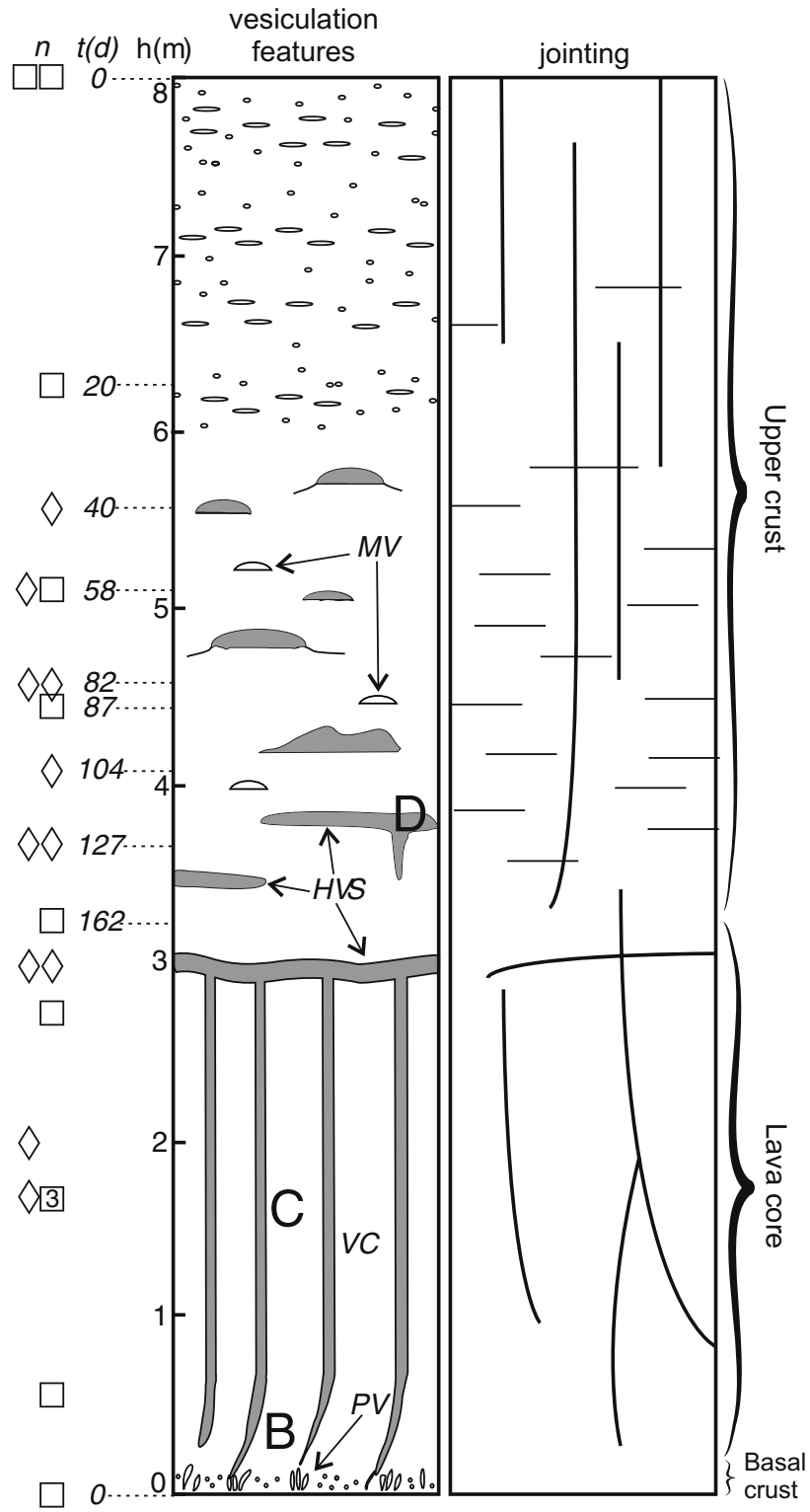

Fig. 2 a Simplified log of the Hafnarhraun pāhoehoe lobe. On the left side of the $\log$, location of samples $(n)$, estimated time ( $t$, in days) of solidification after lobe emplacement following the Hon et al. (1994) model (see the "Discussion" section), and approximate height ( $h$, in meters) from the bottom of the lava lobe are shown. Squares depict lava core and crust samples, diamonds segregation samples. Left panel gives the
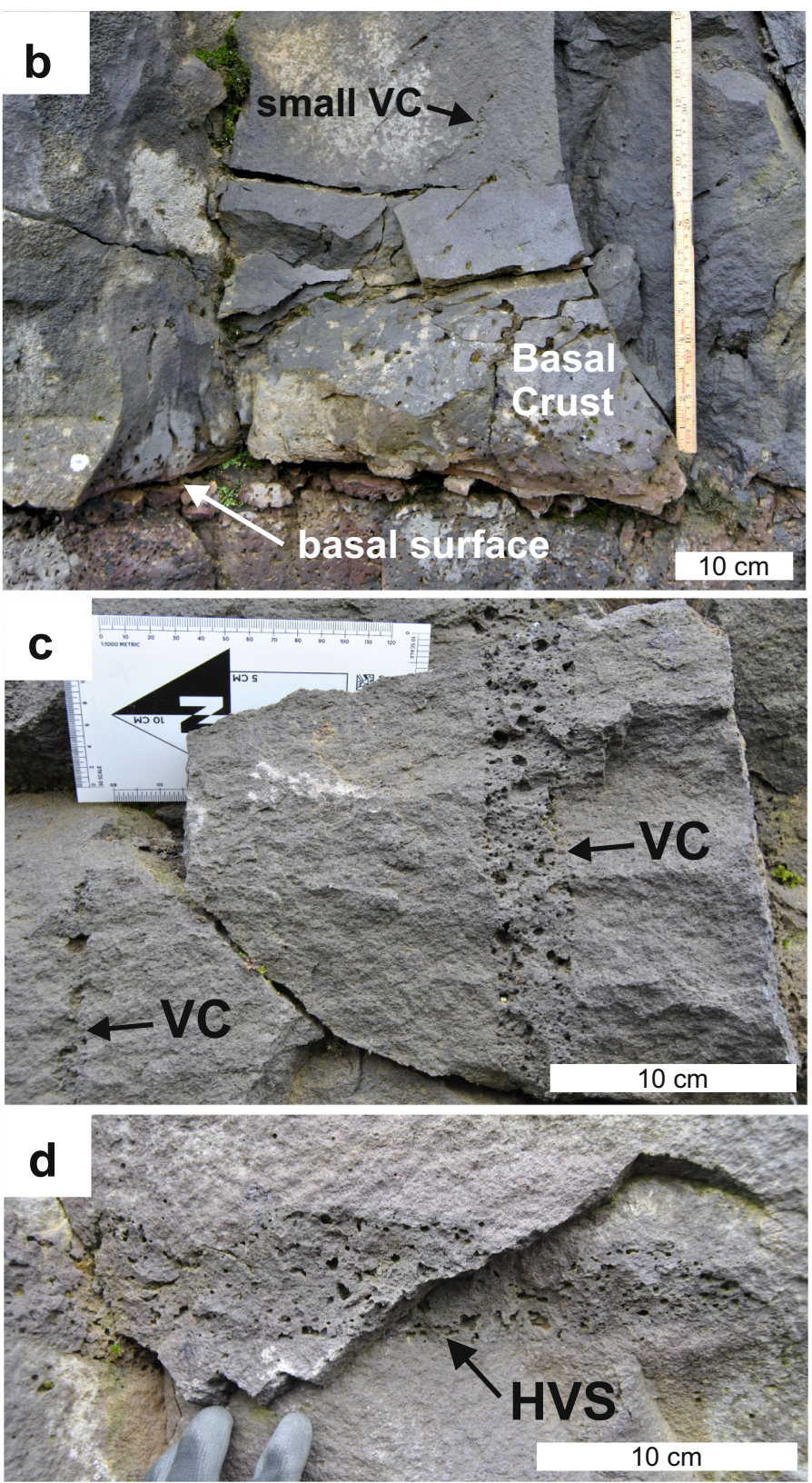

position of photographs $\mathbf{b}, \mathbf{c}$, and $\mathbf{d}$ and depicts vesiculation features with vesicle cylinders (VC) and horizontal vesicle sheets (HVS) marked in gray. MV and PV refer to megavesicles and pipe vesicles, respectively. Right panel shows jointing features formed during cooling and emplacement of the lava. b Basal crust with pipe vesicles, basal surface, and small VC. c Vesicle cylinders (VC). d Horizontal vesicle sheet (HVS)

microphenocrysts do exist even at the very bottom contact of the lava, implying plagioclase crystallization before the lava flow came to halt. The vesicle size in the basal crust is also larger higher up near the lava core so that up to $1 \mathrm{~cm}$ vesicles are found $2 \mathrm{~cm}$ from the quenched basal contact.

The holocrystalline lava core contains 11 vol\% olivine phenocrysts in a groundmass featuring a well-developed subophitic texture of Ca-plagioclase and augite along with groundmass olivine, ilmenite, and magnetite (Fig. 3b). 

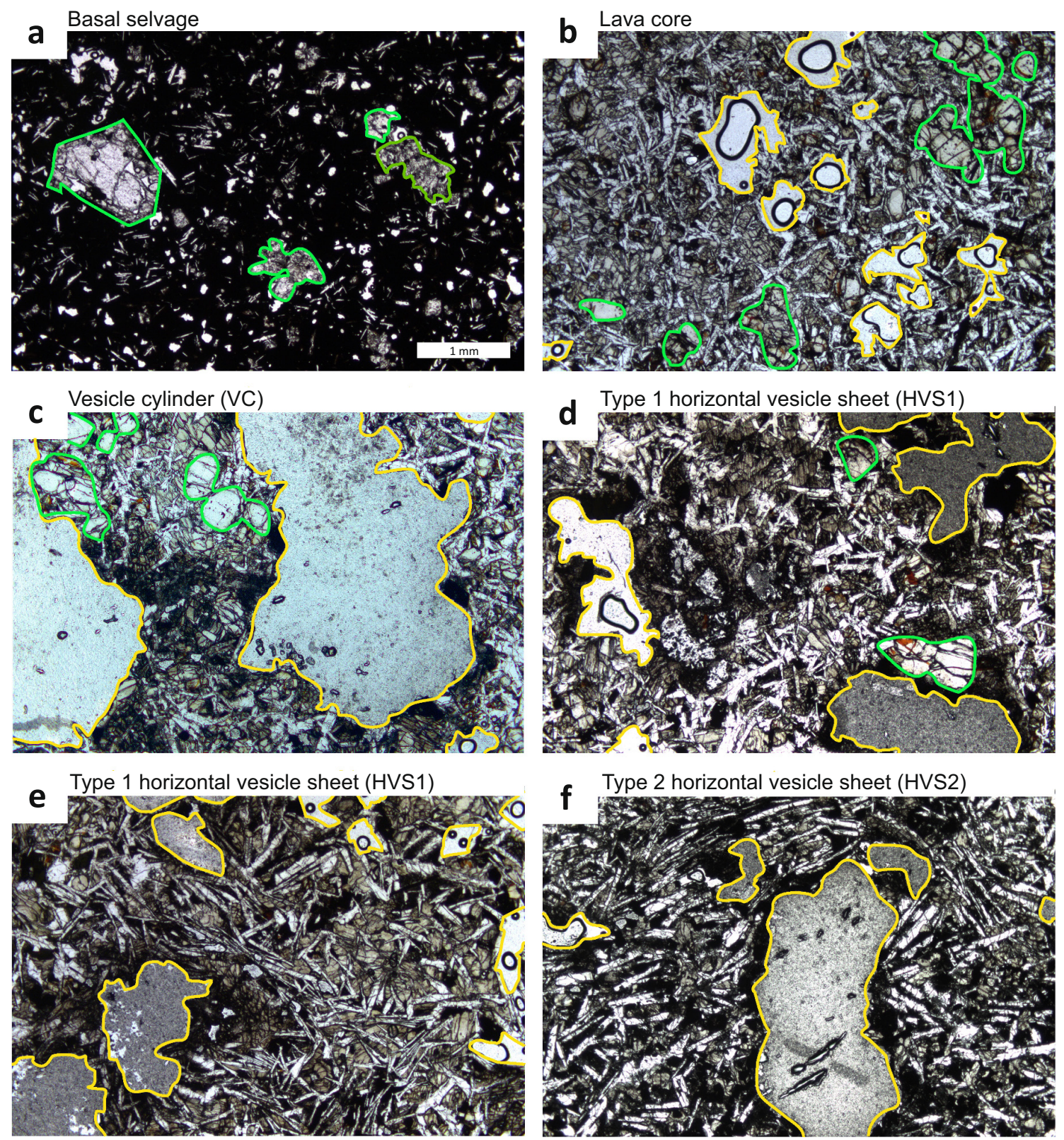

Fig. 3. Photomicrographs in plane-polarized light showing textures of units in the Hafnarhraun lava lobe. a Basal selvage of the basal crust (sample 49TH16). b Lava core (sample 11TH15-G). c Vesicle cylinder (VC, sample 11TH15-D). d Type 1 horizontal vesicle sheet (HVS1, 3 m above the base of the lava, sample 31TH15). e HVS1 (4.5 $\mathrm{m}$ above the

Irregular-shaped vesicles occupy $12 \mathrm{vol} \%$ of the lava core and are typically $0.2-1.0 \mathrm{~mm}$ in diameter (Fig. 3b), although rare vesicles up to $5 \mathrm{~mm}$ in diameter also exist. Vesicles are commonly mantled by microcrystalline groundmass. There are also some rare $(<0.5$ vol\% $)<200 \mu \mathrm{m}$ angular voids and interstitial glass pockets with small anhedral apatite and skeletal magnetite. In the lava core, phenocryst and groundmass olivine crystal cores are $\mathrm{FO}_{77-79}$ and $\mathrm{FO}_{39-69}$, respectively, in composition (Fig. 4a), the plagioclase crystal cores are $\mathrm{An}_{65-}$ 77 (Fig. 4b), and augite compositions vary between lava base, sample 33TH15). f Type 2 horizontal vesicle sheet (HVS2, 4.1 $\mathrm{m}$ above the lava base, sample 35TH15). For clarity, olivine phenocrysts and microphenocrysts are outlined in green and vesicles in yellow (except for image "a" with abundant small vesicles). Scale for all panels is in panel a

$\mathrm{En}_{38} \mathrm{Fs}_{28} \mathrm{Wo}_{34}$ and $\mathrm{En}_{47} \mathrm{Fs}_{15} \mathrm{Wo}_{39}$ (Fig. 4c). Olivine phenocrysts commonly have variably thick $\mathrm{Fo}_{29-72}$ rims occasionally grow to the surrounding groundmass partly enclosing tips of plagioclase laths. In all examined samples, segregations included, magnetite shows subsolidus exsolution to ilmenite forming trellis-type lamellae.

The segregations are distinguished from the lava core and crust by abundant rounded vesicles (23-33 vol\%), by slightly darker color, and by larger grain size, especially evident when comparing the size of plagioclase laths (Fig. 3c, d, and e). The 
Fig. 4. a Variation in forsterite (Fo) content in olivine cores within the Hafnarhraun lava lobe. Phenocryst and groundmass olivine marked with circles and crosses, respectively. Propagated $2 \sigma$ instrumental error is smaller than the symbol size. $\mathbf{b}$ Plagioclase composition in different units of the Hafnarhraun lava lobe. Propagated average $2 \sigma$ instrumental uncertainty of Ancontent (approximately \pm 1 cation $\%$ ) is illustrated. Crystal cores and rims are marked with circles and crosses, respectively. Rim compositions were analyzed $\sim 10-15$ $\mu \mathrm{m}$ from the crystal edge. $\mathbf{c}$ Core compositions of augite crystals in the Hafnarhraun pāhoehoe lava shown in the pyroxene quadrilateral
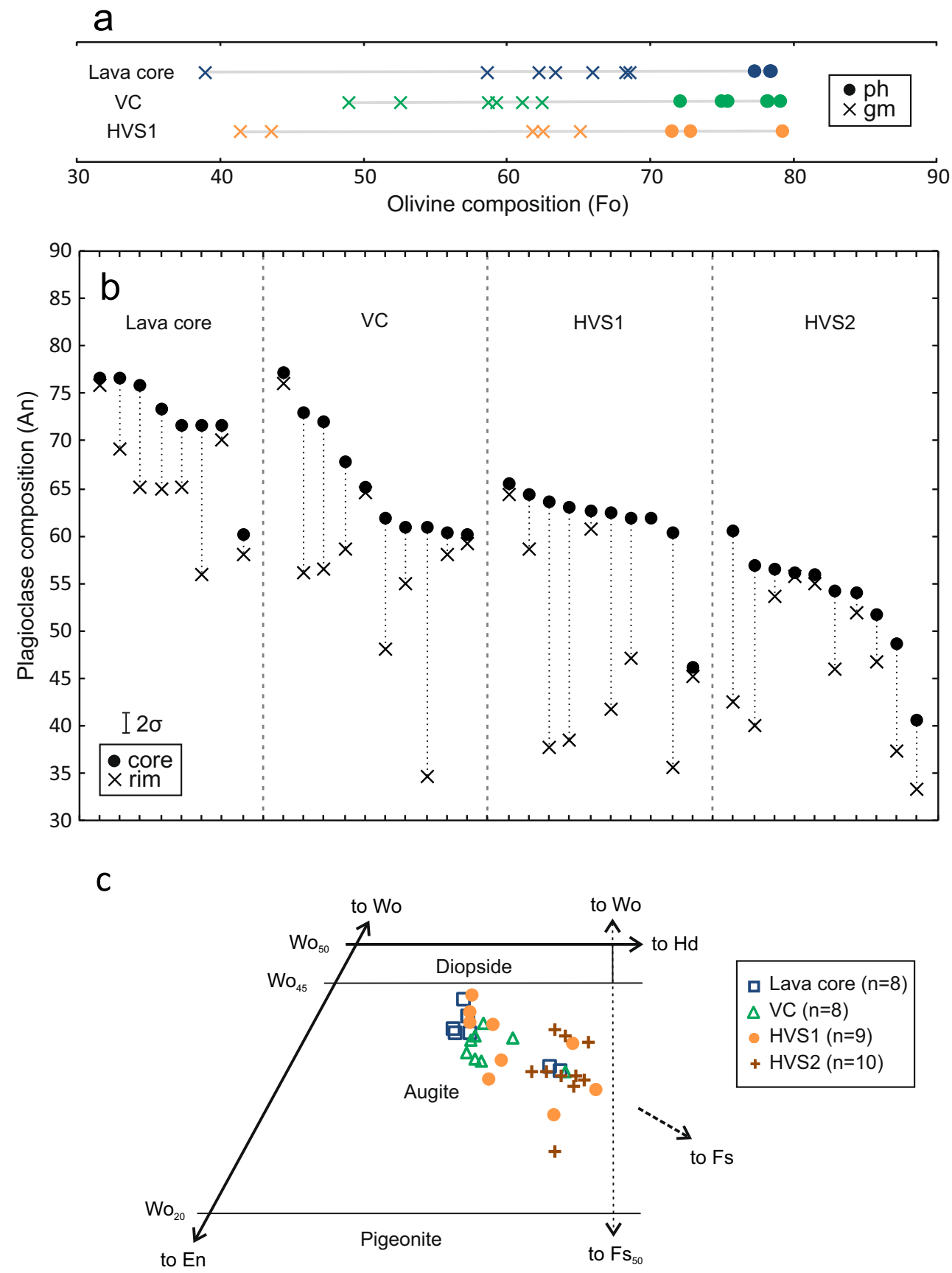

mineral assemblages in VC and HVS1 are, however, almost identical to those in the lava core with subophitic $\mathrm{Ca}$ plagioclase and augite, and olivine phenocrysts (Table 1, Fig. 3). The amount of olivine phenocrysts decreases from VC (13 vol\%) to HVS1 (0-5 vol\%). The composition of olivine, plagioclase and augite in the lava core, VC, and HVS1 overlap, although HVS1 seem to lack the most primitive calcic variety of plagioclase $\left(\mathrm{An}_{76-71}\right)$ present in the lava core and VC (Fig. 4b), and augite in HVS1 tends to be more ferrous (Fig. 4c) compared to $\mathrm{VC}$ and lava core.
The HVS2 are, on thin section scale, petrographically distinct in comparison with all other units in the lava lobe (Table 1, Fig. 3f). They are nearly devoid of olivine (only a few grains) and display a texture of flow-aligned plagioclase in a groundmass of augite, euhedral magnetite and ilmenite, and microcrystalline glass with skeletal magnetite (Fig. 3f). Plagioclase in HVS2 is relatively sodic $\left(\mathrm{An}_{<63}, \mathrm{Fig} .4 \mathrm{~b}\right)$, and augite crystals in the HVS2 are distinctively Fe-rich $\left(\mathrm{Fs}_{>25}\right.$, Fig. 4c). At the contacts of HVS2 and the host lava, plagioclase laths are aligned parallel to the contact in 

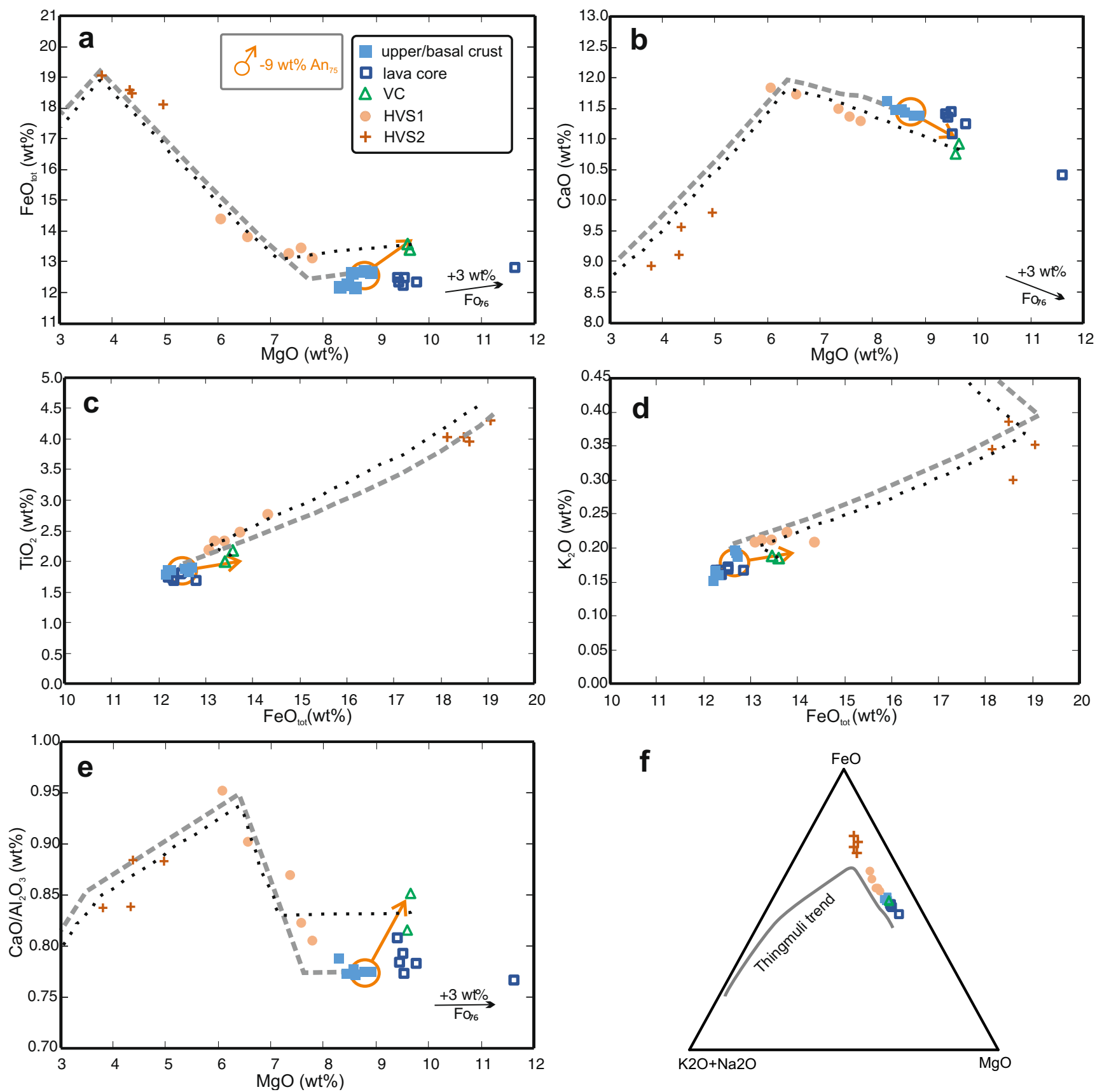

Fig. 5. Major element composition of the Hafrarhraun samples shown in $\mathrm{MgO}$ vs. $\mathrm{FeO}_{\text {tot }}$ (a), $\mathrm{MgO}$ vs. $\mathrm{CaO}$ (b), FeO tot vs. $\mathrm{TiO}_{2}$ (c), $\mathrm{FeO}_{\text {tot }}$ vs. $\mathrm{K}_{2} \mathrm{O}$ (d), $\mathrm{MgO}$ vs. $\mathrm{CaO} / \mathrm{Al}_{2} \mathrm{O}_{3}$ (e), and $\mathrm{FeO}-\mathrm{K}_{2} \mathrm{O}+\mathrm{Na}_{2} \mathrm{O}-\mathrm{MgO}$ (f) diagrams. Instrumental errors $(2 \sigma)$ for the compositions and elemental ratios are smaller than or equal to the symbol size. Calculated residual liquid compositions are marked by gray dashed and black dotted lines for $1 \mathrm{~atm}$ fractional crystallization of "host lava" and "VC" initial compositions, respectively. The "host lava" composition corresponds to the average

microcrystalline matrix. The rare olivine crystals found from HVS2 in the studied thin sections were anhedral and mantled by oxide.

\section{Whole-rock geochemistry}

The whole-rock geochemical variation in the Hafnarhraun lobe is illustrated in Fig. 5 and Fig. 6, and the analytical data can be found in Table 2 and Online Resource 1. The lava core is 


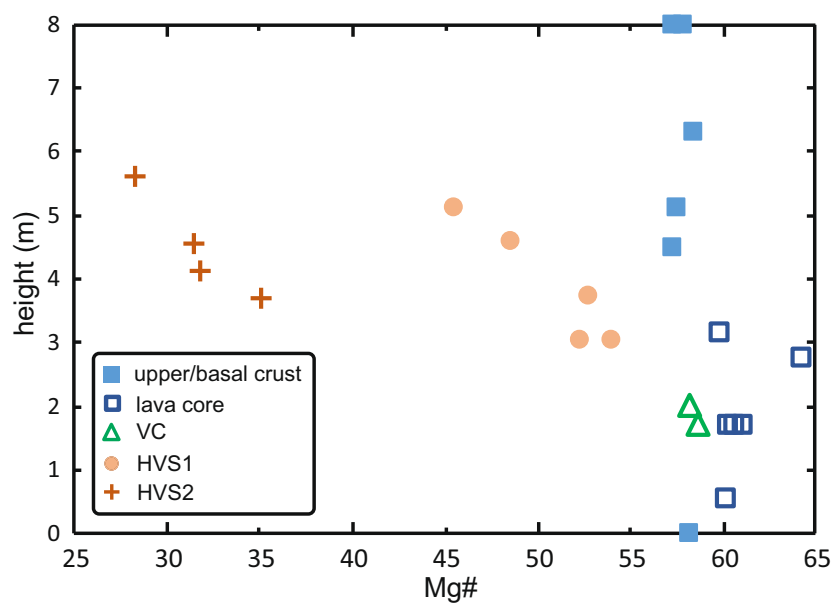

Fig. 6. Height above lava base vs. $\mathrm{Mg} \#(\mathrm{Mg} \#=$ molar $100 \times \mathrm{Mg} /(\mathrm{Mg}+$ $\left.\mathrm{Fe}^{2+}\right), \mathrm{Fe}^{2+}=0.9 \mathrm{Fe}_{\text {tot }}$ ) for the Hafnarhraun samples

olivine tholeiite with a magnesium number $(\mathrm{Mg \#}=$ molar 100 $\left.\times \mathrm{Mg} /\left(\mathrm{Mg}+\mathrm{Fe}^{2+}\right), \mathrm{Fe}^{2+}=0.9 \mathrm{Fe}_{\text {tot }}\right)$ of $60-61$, with one sample (42TH15) from underneath the extensive lowermost HVS with

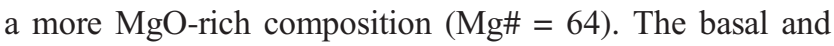
upper crust samples from the top and bottom of the flow have consistently lower Mg\# (57-58) than the lava core (Fig. 6).

VC show only slight compositional difference from the lava core or crust samples (Fig. 5, Table 2). Although they are somewhat richer in $\mathrm{FeO}_{\text {tot }}, \mathrm{TiO}_{2}, \mathrm{~K}_{2} \mathrm{O}, \mathrm{Na}_{2} \mathrm{O}, \mathrm{P}_{2} \mathrm{O}_{3}$, and $\mathrm{V}$, and poorer in $\mathrm{Al}_{2} \mathrm{O}_{3}, \mathrm{CaO}$, and $\mathrm{Cr}$ compared to the lava core, their $\mathrm{MgO}$ content and many of the trace elements are nearly the same as in the lava core samples. From the two samples taken from VC, the stratigraphically higher of the two is slightly more ferrous and incompatible element enriched.

HVS1 have Mg\# 46-54, whereas HVS2 have Mg\# equal or below 35. The compositional gap between these two segregation sheet types is notable in all major elements (Fig. 5). The $\mathrm{FeO}_{\text {tot }}$ of the HVS1 peak at $14.3 \mathrm{wt} \%$, whereas HVS2 reach $19.1 \mathrm{wt} \% \mathrm{FeO}_{\text {tot }}$. The HVS2 also have the highest concentrations of incompatible elements, notably $\mathrm{Zr}, \mathrm{Y}$, and $\mathrm{V}$, and strikingly low $\mathrm{Cr}$ in comparison with other sample types (Table 2). Both HVS1 and HVS2 tend to have more $\mathrm{FeO}_{\text {tot }}$ and incompatible element upward in the lobe. This is the clearest in the variation in Mg\# (Fig. 6), but can also be illustrated by plotting other elements.

\section{Discussion}

\section{Time constraints of lava lobe formation}

It is crucial to understand the temporal relationships of the units in the lava lobe. According to Hon et al. (1994), the downward solidification of pāhoehoe upper crust is progressive during lava emplacement, and hence, the final thickness of the upper crust ( $H_{\mathrm{c}}$, in meters) can be related to the emplacement time of the lobe ( $t$, in hours) by $t=164.8 \times \mathrm{H}_{\mathrm{c}}{ }^{2}$. Based on this, the downward solidification of the Hafnarhraun upper crust took around 160 days (Fig. 2a), after which the lava core would have taken about a further month to solidify completely. Consequently, if we interpret that at least the HVS1 represent accumulations of VC to the base of the gradually solidifying upper crust (as usually done, cf. Self 1998), HVS1 higher in the crust must have formed before HVS1 lower in the crust (Fig. 2a). In addition, as the lava core is the last part of the lobe to solidify, segregations within it are the youngest.

\section{Temporal evolution of the host lava}

In the studied Hafnarhraun lava lobe, the lava core is more magnesian than the crust (Fig. 6). This compositional variation suggests more olivine in the lava core than in the crust. Addition of $3 \mathrm{wt} \%$ of $\mathrm{Fo}_{76}$ olivine (the average composition of olivine phenocrysts in the lobe) to the crust delivers the composition of the lava core (olivine-accumulation vector in Fig. 5). Sample 42TH15, taken from the lava core just below the lowest extensive HVS, is particularly rich in $\mathrm{MgO}$ (11.7 wt\%, Fig. 5), and its composition suggests $\sim 10 \mathrm{wt} \%$ relative enrichment in olivine. Gravitational settling may have enriched the lava core in olivine phenocrysts during the lifespan of the lobe. Additionally, the lava in the lava core may have been hotter and thus richer in olivineforming elements than the lava that formed the crust. The lava that formed the crustal selvages had probably cooled and fractionated olivine on transit from the vent. The lava core, however, represents a later phase in the effusive sequence, when lava likely moved within a well-insulated lava tube network. Because of this enhanced insulation (cf. Harris and Rowland 2009), melt in the lava core may have stayed hotter, fractionated less olivine, and remained rich in $\mathrm{MgO}$.

\section{Differentiation of segregations by fractional crystallization}

To evaluate whether the melt segregations in the Hafnarhraun pāhoehoe lobe are differentiated melts produced by fractional crystallization of the lava lobe, we modeled the fractional crystallization of the lobe and composition of derivate melts along the liquid line of descent (LLD, Fig. 5) with COMAGMAT-5.2.2. (Ariskin 1999; Ariskin et al. 2018) software. As the non-fractionated initial lava composition, we used the average composition of the quenched top and bottom lava selvages (solid line in Fig. 5), referred as "host lava" herein. As discussed earlier, the chemical variability within lava core and crustal units is controlled by the amount of liquidus olivine (either as phenocrysts or in the melt), which is the first crystallizing phase. Hence, the LLD trajectory is rather indifferent to the selection of initial composition from the available crust and lava core samples. We also calculated the composition of residual melts generated in fractional 
己己ة

黄点

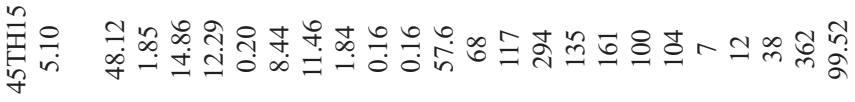

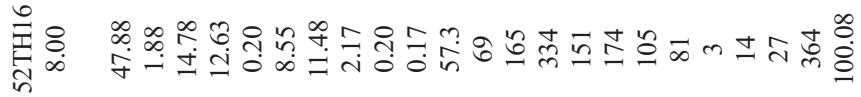

苞的

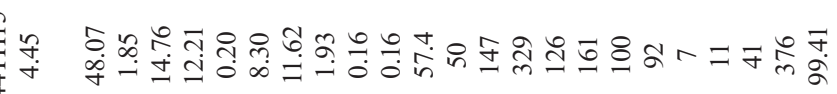

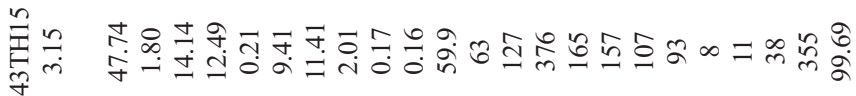

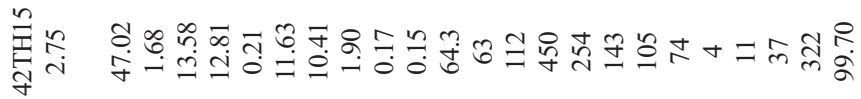

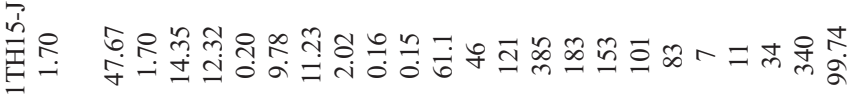

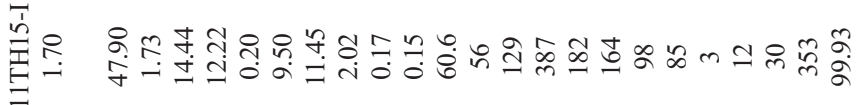

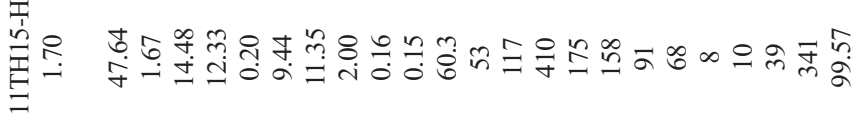

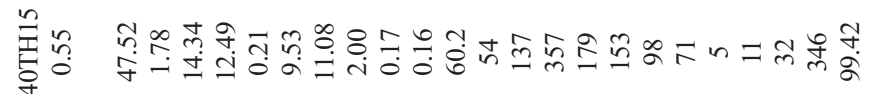

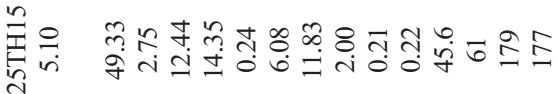

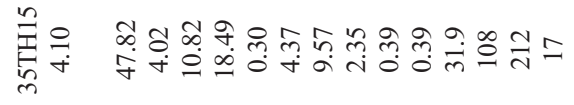

点展 焉

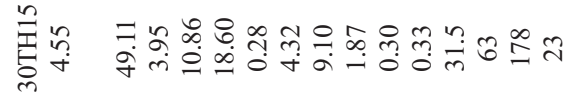

$$
\text { त }
$$

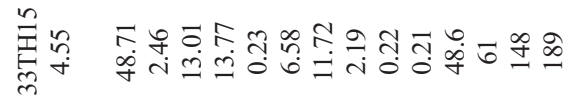

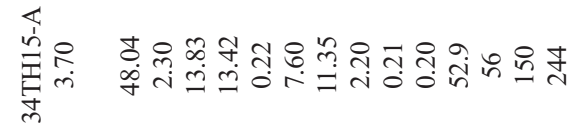

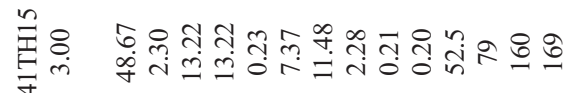

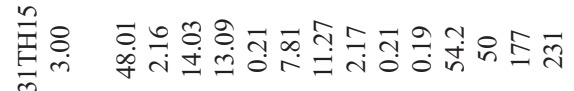

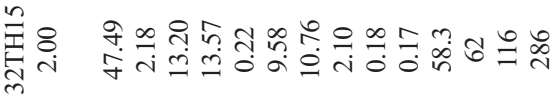

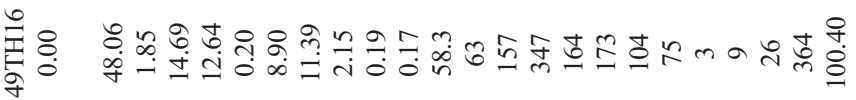

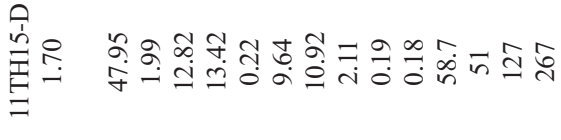

$\frac{\text { ก }}{\frac{0}{0}}$

量

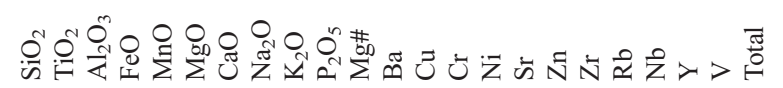

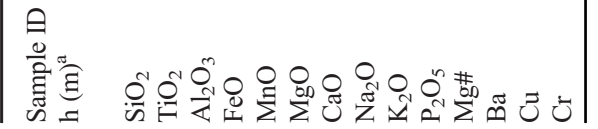


crystallization of a VC-like initial melt, as these were the best fits for HVS1 compositions (stippled line in Fig. 5). The order of fractionating phases is olivine, olivine + plagioclase, olivine + plagioclase + augite, and olivine + plagioclase + augite + magnetite. The first modeled mineral on liquidus is $\mathrm{Fo}_{80}$ olivine that develops to $\mathrm{Fo}_{78}$ before $\mathrm{An}_{78}$ plagioclase is stabilized. The first modeled augite to fractionate has the composition of $\mathrm{En}_{46} \mathrm{Fs}_{13} \mathrm{Wo}_{40}$. This modeled crystallization assemblage corresponds well to the observed phenocryst and groundmass mineralogy in the Hafnarhraun lava lobe (compare to Fig. 4).

The VC in Hafnarhraun are compositionally nearly similar to the lava core and crust (Fig. 5), and thus differ from the VC reported elsewhere that correspond to residual melts after 36$60 \%$ crystallization of the host lava (Rogan et al. 1996; Stephenson et al. 2000; Hartley and Thordarson 2009; Sigmarsson et al. 2009). In fact, the Hafnarhraun VC do not correspond to any likely residual melt produced by fractional crystallization of the host lava, as the expected fractionate from olivine tholeiitic magma always depletes the residual liquid in $\mathrm{MgO}$ (Fig. 5). However, crystallizing and removing $\sim 9 \mathrm{wt} \% \mathrm{An}_{75}$ plagioclase from the host lava results in a VClike composition with relatively high $\mathrm{MgO}(9.6 \mathrm{wt} \%)$ and $\mathrm{FeO}$ (13.5 wt\%), low $\mathrm{CaO}$ (10.8 wt\%), and $\mathrm{Al}_{2} \mathrm{O}_{3}$ (13.01 wt\%) along with minor enrichment in incompatible elements (Fig. $5)$.

The major oxide composition of HVS1 resembles that of $\mathrm{VC}$ that were fractionated further and lost most or all of their olivine phenocryst cargo in the process (Fig. 5, stippled line). This is consistent with the fewer olivine phenocrysts in those HVS1 that are positioned higher in the lava lobe. Depending on the initial composition (host lava or VC, solid or stippled line in Fig. 5), our fractional crystallization models produce HVS1-like residual liquids after either 17-38 wt\% (host lava) or 11-23 wt\% (VC) fractional crystallization. Rayleigh fractionation of $\mathrm{TiO}_{2}$ and $\mathrm{Zr}$, in turn, suggests host lava crystallinity of $13-39 \mathrm{wt} \%$ before segregation of the HVS1 forming residual melt.

HVS2 represent the most fractionated liquids of the analyzed section, and their composition fits that of simple residual melts of the host lava generated by fractional crystallization. The model residual melts attain HVS2-like compositions after 50-60 wt\% fractional crystallization from the host lava, corresponding to removal of 12-13 wt\% olivine, 24-28 wt\% plagioclase, and 12-17 wt\% augite (Fig. 5). Correspondingly, relative enrichment in $\mathrm{TiO}_{2}, \mathrm{~K}_{2} \mathrm{O}$, and $\mathrm{Zr}$ in HVS2 suggests 53-57 wt \%, 36-50 wt\%, and 56-67 wt \% crystallinity in the host lava, respectively, before residual melt segregation.

\section{Co-genetic formation of VC and HVS1}

We have shown that VC compositions in Hafnarhraun do not correspond to any expected residual melt produced by fractional crystallization of the host lava. Comparable VC that do 
not represent simple differentiated liquids of the host lava have been reported earlier by Caroff et al. (2000) and Kuritani et al. (2010). Caroff et al. (2000) published segregation compositions that included a VC (TB10B) with a composition similar to its host lava. They noted that this $\mathrm{VC}$ is cumulative in olivine phenocrysts, but did not discuss its genesis further. Kuritani et al. (2010) reported VC enriched in both incompatible elements and $\mathrm{MgO}$ compared to the surrounding lava, and envisioned that these $\mathrm{VC}$ were formed by selective fractionation of plagioclase and pyroxene from the lava when olivine-bearing interstitial melt was extracted from partly crystalline lava core. The Hafnarhraun VC are reminiscent of those reported by Kuritani et al. (2010), as selective crystal fractionation applies as a first-order explanation for the composition of Hafnarhraun VC as well.

As we envision it, the simplest, yet probably unrealistic model to explain the composition of Hafnarhraun VC, is illustrated in Fig. 7a. In this model, olivine crystals and residual liquid are separated from a crystal mush near the lower crystallization front of the lava base, while plagioclase ( $9 \mathrm{wt} \%$ ) remains in the lava base. This model of genesis, although able to reproduce the detected depletion in plagioclase bearing elements in $\mathrm{VC}$, is problematic because of the indicated low crystallinity of the crystal mush during $\mathrm{VC}$ segregation $(\sim 16$ $\mathrm{wt} \%$ ), and we struggle to understand how dense olivine phenocrysts were drawn to the upwelling $\mathrm{VC}$ while plagioclase was not. Hence, we propose an alternative model, illustrated in Fig. 7b, in which VC forming residual melt (liquid + vapor) first segregates from olivine + plagioclase + liquid + vapor

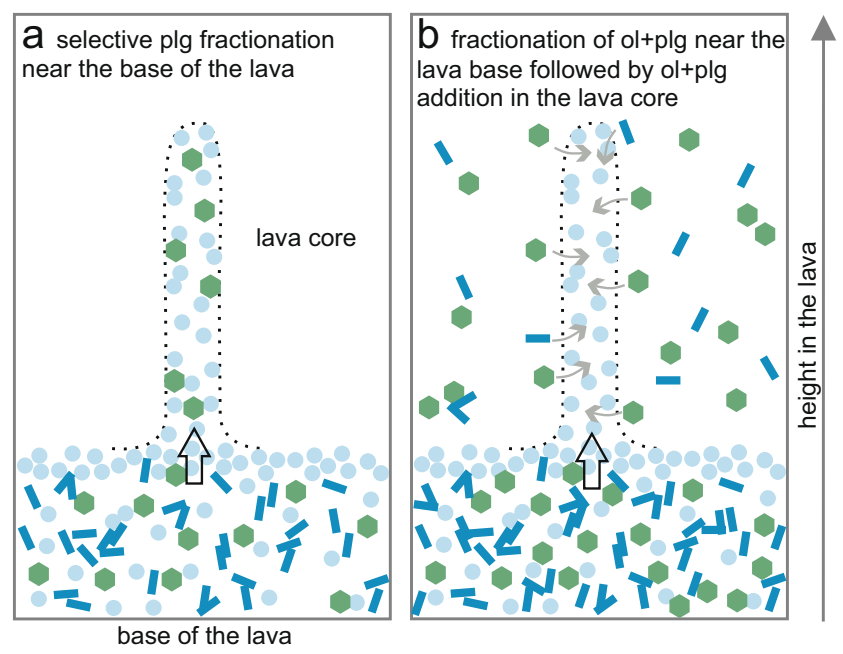

Fig. 7. Illustration of two petrogenetic models for the formation of $\mathrm{VC}$. Pale blue circles are vapor bubbles, green hexagons olivine (ol), and dark blue rectangles plagioclase (plg). Bottom of the images corresponds to the lava base and top to the center parts of the lava core. a A model of selective derivation of olivine and vapor saturated interstitial melt from ol+plg+melt+vapor mixture near the base of the lava, i.e., plagioclase is fractionated from the host lava to form VC. b Our preferred model of intercrystalline melt sequestering from ol+plg+liquid+vapor mush near the lava base followed by olivine and minor plagioclase addition in the lava core mush near the lava base and later accumulates olivine phenocrysts and plagioclase microphenocrysts in ascent in the lava core. The segregation of $\mathrm{VC}$ melt must have occurred after a minimum of $\sim 13-16 \mathrm{wt} \%$ fractional crystallization of $\sim 6-7$ wt $\%$ olivine + 7-9 wt $\%$ plagioclase near the lava base, and in this scenario, only $\sim 5-6 \mathrm{wt} \%$ olivine phenocrysts needs to be added to the $\mathrm{VC}$ in the lava core to reproduce the observed $\mathrm{VC}$ composition. Anyhow, it is likely that the crystallinity near the lava base must have been higher (up to $25 \%$ ) to allow effectively melt+vapor separation from the crystal phases (Philpotts et al. 1998). In this scenario, more olivine and variable amounts of plagioclase must have accumulated in VC while it was forming in the liquid lava core (Fig. 7b). The detected 13 vol\% olivine phenocrysts in $\mathrm{VC}$ indicate high amount of olivine accumulation to VC in the lava core, but can also be, at least partly, attributed to the in situ growth of the olivine phenocrysts within $\mathrm{VC}$.

In the two-stage model of $\mathrm{VC}$ formation outlined in Fig. $7 \mathrm{~b}$, the depletion in plagioclase bearing elements in $\mathrm{VC}$ reflects different levels of crystallization between the base of the lava (origin of VC) and lava core (source of entrained crystal assemblage). This model of formation is easier to conceive than selective removal of plagioclase, or selective segregation of olivine and melt from a crystal mush (e.g., Fig. 7a). In addition, the model is consistent with field evidence suggesting VC derivation from near the lava base and strongly supported by the detected high-Fo olivine phenocrysts (Table 1 and Fig. 4a) and Ca-rich plagioclase in VC (Fig. 4b), which are clear indications of crystal accumulation to VC.

Although only the lowermost HVS1 is visibly fed by the underlying $\mathrm{VC}$, the petrographic and compositional similarity of VC and HVS1 suggest that all HVS1 are accumulations of $\mathrm{VC}$ material to the bottom of the solidifying upper crust at different stages of lava lobe development. In particular, the similar $\mathrm{CaO}$ depletion in $\mathrm{HVS} 1$ and $\mathrm{VC}$ in comparison with the modeled residual liquids of the host lava (Fig. 5b), and the fact that HVS1-like melts are produced by fractional crystallization of a VC-like initial composition, point to co-genetic relationship between VC and HVS1. The increasing level of differentiation in HVS1 composition higher up in the lava lobe (Fig. 6) may be consequential to lesser contamination with primitive olivine and plagioclase higher in the lobe, and preferential uprising of the residual liquid in comparison with in situ fractional crystallization assemblage in ascending VC.

Our model of two-stage formation of Hafnarhraun VC and their co-genetic relation with HVS1 requires the lava core to have been mostly liquid during VC ascent and HVS1 formation. Whatever the physical process that segregated $\mathrm{VC}$ at the base of the lava flow-gas-filter pressing (Anderson et al. 1984), Rayleigh-Taylor instability (Costa et al. 2006), or mushy convection (Fowler et al. 2014) - VC must have later ascended within the lava core in a manner that allowed contamination with primitive mineral phases. In addition, the lava 
core must have been fairly liquid to facilitate horizontal spreading of HVS1 below the lower crystallization front of the upper crust.

\section{Formation of HVS2}

HVS2 are chemically and mineralogical distinct from VC and HVS1, and their composition suggests that they are segregated residual melts of the lava lobe. The sample $34 \mathrm{TH} 15$ with a HVS1-type lower and HVS2-type upper part could be seen suggestive of HVS2-like residual melt derivation from HVS1. However, expulsion of sufficient residual melt from the underlying HVS1 (34TH15-A) to make the HVS2-like upper part (34TH15-B), which is $10-30 \%$ of the total sheet volume, should have effectively depleted the underlying HVS1 of incompatible elements and we do not see this. In all, we did not locate incompatible-element-depleted layers of "solid residue" from the upper crust or lava core from which the HVS2 residual melt was removed. Hence, it is likely that the segregation of HVS2 mobilized residual melt over a relatively large area in the lava lobe and the chemical depletion related to removal of HVS2 melt was widely distributed. HVS2 likely formed at a late stage of lava flow cooling, when residual melts of the lava lobe seeped into megavesicles and other voids within the upper crust by gas-filter pressing (Anderson et al. 1984) or other mechanism. Megavesicles are very common in the top part of HVS1, and this could explain why HVS2 formed directly on the top of HVS1 in sample 34TH15.

\section{Differentiation of Hafnarhraun pāhoehoe lobe}

A model of the evolution of the Hafnarhraun lava lobe is shown in Fig. 8. During periods when lava effusion within the lobe shortly stalls or weakens, VC form in response to the separation of vapor-saturated liquids from the solidifying lava base and act as sites of material transport from the bottom to the top of the lava core. During these magmatic lulls, potentially extensive HVS1 are generated as VC-fed material accumulates beneath the lower solidification front of the upper crust (Fig. 8c). However, only a small portion of the HVS1 are preserved in the Hafnarhraun lava flow, as pulses of new magma entering the lava tube system occasionally flush the

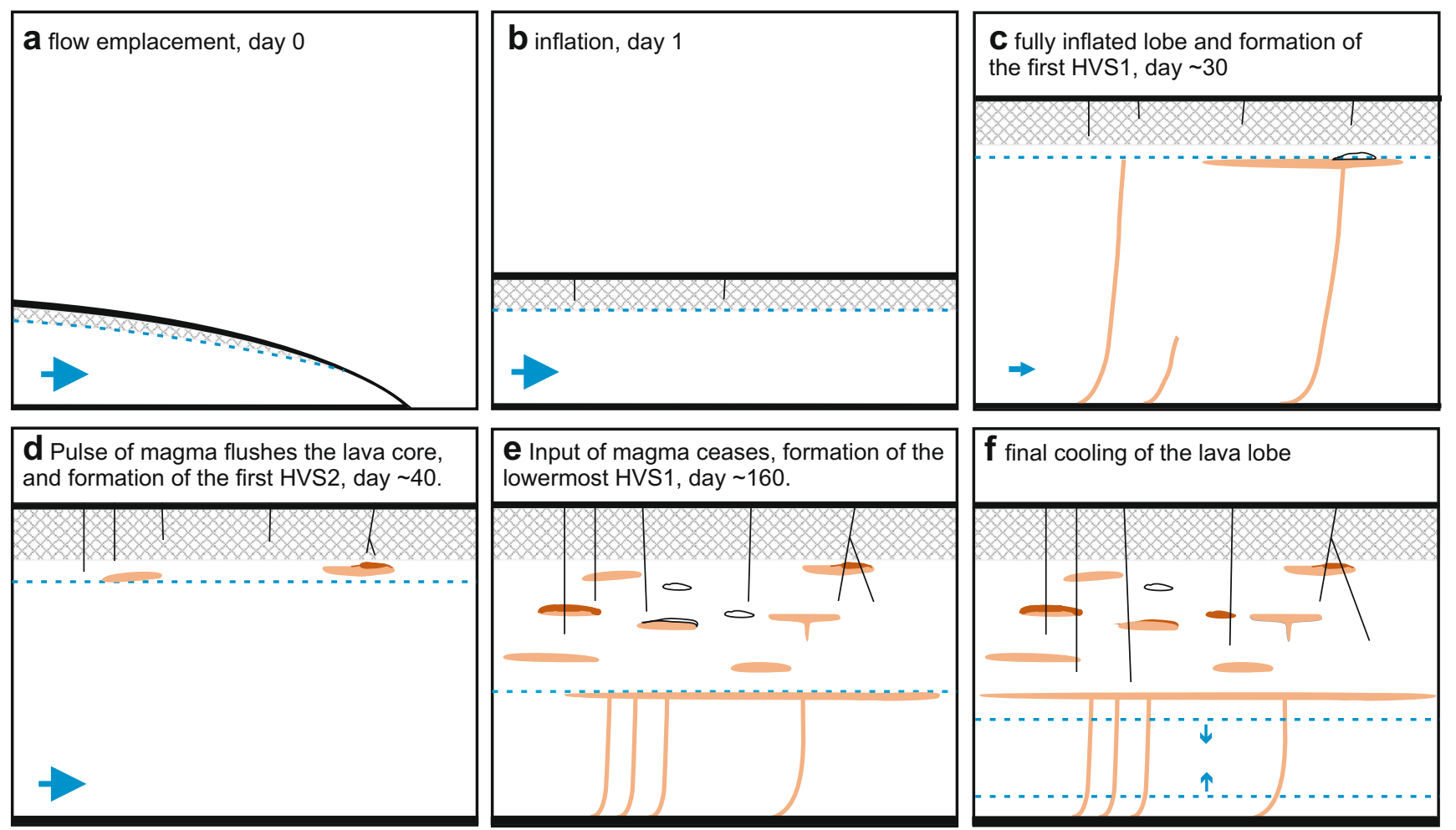

Fig. 8. Cartoon depicting the evolution of the Hafnarhraun pāhoehoe lobe from emplacement to solidification. Vesicular portion of the upper crust is marked in cross-hatching, basal zone in black, and segregation features in beige (VC and HVS1) and brown (HVS2). Megavesicles illustrated as hollow shapes in the upper crust. The blue arrow depicts the magma flow intensity and direction within the lava, and the blue stippled line marks the level of solidification front(s). Stages of development: a Emplacement of a lobe. b Lobe inflation. $\mathbf{c}$ As the input of new magma to the lobe is limited, crystallization commences near the base of the lobe and VC form. Some VC ascent to the base of the upper solidification front forming HVS1. d Pulse of new fresh magma to the lava lobe disturbs the formation of segregations and flushes the lava core; relicts of HVS1 segregations are preserved. Unrelated to this event, the first HVS2 is formed high in the upper crust, as highly evolved interstitial melts seep to a deflating gas pocket above HVS1. e After months of variable effusion rate in the lava lobe, fresh magma is no longer delivered to the system, and the lowermost extensive HVS1 is formed. f Final cooling and crystallization preserves VC in the lava core, and further HVS2 are formed in the upper crust 
crystallizing core of the segregation features (Fig. 8d). The lowermost HVS1 remains extensive, as it forms during the final stage of lava cooling as the lava lobe becomes inactive (Fig. 8e). HVS2 form independently of VC, as vesicular residual melts seep to void spaces in the upper crust (Fig. 8d-f) in later stages of the lobe cooling. The two different mechanisms of HVS formation, now identified within a single lava flow, may explain some of the diverging observations of HVS development in earlier studies, compare, for example, Hartley and Thordarson (2009) and Kuritani et al. (2010).

\section{Magma differentiation in crustal magma storage zones}

Volatile-driven magma differentiation, at least partly analogous to segregation formation in Hafnarhraun, may take place in shallow crustal magma storage zones (e.g., chambers and sills) and has been evoked to explain silicic segregation lenses and sheets in intrusions (Carman 1994; White 2007; Zavala et al. 2011) and formation of crystal-poor FeTi-basalts (Sigmarsson et al. 2009). Andesitic to rhyolitic magmas are most likely to experience crystal-melt separation aided by volatiles due to their high volatile content and expansion during vapor exsolution (Sisson and Bacon 1999; Parmigiani et al. 2016), but also basaltic magma may be affected, at least during slow ascent in conduits and in intrusions at shallow crustal levels. Additionally, upper crustal magmas may feature vapor-aided convection (or "bubble-driven convection", cf. Cardoso and Woods 1999) that could occur in a similar manner to that observed within the Hafnarhraun lava lobe, i.e., driven by VC accommodated mass transfer from the bottom to the top of system. This vapor-aided mass movement could explain, in some cases, signs of convection in small and shallow intrusions that are not expected to undergo significant thermal convection.

We have demonstrated that the Hafnarhraun VC are not simple residual liquids of the host lava, generated by fractionation of equilibrium mineral phases, but residual liquids that have accumulated primitive olivine and plagioclase. Volcanic rocks with crystal cargoes of more primitive character than in equilibrium with the carrier melt are common (e.g., Davidson et al. 2007; Thomson and Maclennan 2013; Neave et al. 2015). Usually, these primitive crystals are thought to accumulate to evolved melts from disaggregated crystal mushes; however, in the Hafnarhraun lava lobe, VC accumulated primitive crystals from the nearly liquid portion of the lobe when VC-melts ascended through it. Although the accumulation of primitive phenocrysts to magmas often occurs in mid- to lower-crustal settings, and significant vapor is unlikely to be present at these pressures in most basaltic magmas, the Hafnarhraun VC are a novel example of crystal accumulation and basalt differentiation, applicable to at least shallow crustal settings.

\section{Conclusions}

Our work gives additional support to the concept of lava degassing as a significant differentiation mechanism in pāhoehoe lavas. We found that the Hafnarhraun VC are not simple segregated residual melts of the host lava, but rather formed in a two-stage process involving separation of vaporsaturated residual melt in the crystallizing base of the lava followed by accumulation of primitive crystals in the nearly liquid lava core. Furthermore, we suggest that the Hafnarhraun HVS formed by two different processes: (i) accumulation of VC-transported segregated material to the lower solidification front of the upper crust at the top of the lava core and (ii) later seepage of evolved and vapor-saturated melts into void spaces in the upper crust of the lava lobe. Overall, exsolution of volatiles promotes transfer of residual liquid from the bottom to the top of a crystallizing pāhoehoe lava core in thick, slow-cooling lobes. In shallow crustal levels, similar processes may drive mass transfer and crystal-melt separation in magmatic intrusions, potentially promoting crystal accumulation in segregated residual melts and leading to differentiated magma compositions not expected by fractionation of equilibrium mineral phases.

Acknowledgments The Nordic Volcanological Center funded this work 2015-2017. We thank Robert A. Askew and Leó Kristjánsson for the aid in sampling, Atli Hjartarson and Guðmundur H. Guðfinnsson for the help in sample preparation and microprobe analyses, and Richard J. Brown for the editorial handling. Comments from Kaisa Nikkilä, Scott Rowland, and anonymous reviewer significantly improved the manuscript.

Funding information Open access funding provided by University of Helsinki including Helsinki University Central Hospital.

Open Access This article is distributed under the terms of the Creative Commons Attribution 4.0 International License (http:// creativecommons.org/licenses/by/4.0/), which permits unrestricted use, distribution, and reproduction in any medium, provided you give appropriate credit to the original author(s) and the source, provide a link to the Creative Commons license, and indicate if changes were made.

\section{References}

Anderson AT, Swihart GH, Artioli G, Geiger CA (1984) Segregation vesicles, gas filter-pressing, and igneous differentiation. J Geol 92: 55-72. https://doi.org/10.1086/628834

Ariskin AA (1999) Phase equilibria modeling in igneous petrology: use of COMAGMAT model for simulating fractionation of ferrobasaltic magmas and the genesis of high-alumina basalt. J Volcanol Geotherm Res 90:115-162. https://doi.org/10.1016/ S0377-0273(99)00022-0

Ariskin AA, Bychkov KA, Nikolaev GS, Barmina GS (2018) The COMAGMAT-5: modeling the effect of Fe-Ni sulfide immiscibility in crystallizing magmas and cumulates. J Petrol 59:283-298. https:// doi.org/10.1093/petrology/egy026

Cardoso SSS, Woods AW (1999) On convection in a volatile-saturated magma. Earth Planet Sci Lett 168:301-310. https://doi.org/10.1016/ S0012-821X(99)00057-6 
Carman MF (1994) Mechanisms of differentiation in shallow mafic alkaline intrusions, as illustrated in the Big Bend area, western Texas. J Volcanol Geotherm Res 61:1-44. https://doi.org/10.1016/03770273(94)00008-5

Caroff M, Maury RC, Cotten J, Clement JP (2000) Segregation structures in vapor-differentiated basaltic flows. Bull Volcanol 62:171-187. https://doi.org/10.1007/s004450000077

Costa A, Blake S, Self S (2006) Segregation processes in vesiculating crystallizing magmas. J Volcanol Geotherm Res 153:287-300. https://doi.org/10.1016/j.jvolgeores.2005.12.006

Darwin CR (1844) Geological observations on the volcanic islands visited during the voyages of H.M.S. Beagle, with brief notices on the geology of Australia and the Cape of Good Hope, being the second part of the Voyage of the Beagle. Smith Elder \& Co., London

Davidson JP, Morgan DJ, Charlier BLA et al (2007) Microsampling and isotopic analysis of igneous rocks: implications for the study of magmatic systems. Annu Rev Earth Planet Sci 35:273-311. https://doi.org/10.1146/annurev.earth.35.031306.140211

Eason DE, Sinton JM, Grönvold K, Kurz MD (2015) Effects of deglaciation on the petrology and eruptive history of the Western Volcanic Zone, Iceland. Bull Volcanol 77:47-27. https://doi.org/10.1007/ s00445-015-0916-0

Fowler AC, Rust AC, Vynnycky M (2014) The formation of vesicular cylinders in pāhoehoe lava flows. Geophys Astrophys Fluid Dyn 109:1-23. https://doi.org/10.1080/03091929.2014.955799

Gibb FGF, Henderson CMB (1992) Convection and crystal settling in sills. Contrib Mineral Petrol 109:538-545. https://doi.org/10.1007/ BF00306555

Gibb FGF, Henderson CMB (2006) Chemistry of the Shiant Isles Main Sill, NW Scotland, and wider implications for the petrogenesis of Mafic Sills. J Petrol 47:191-230. https://doi.org/10.1093/petrology/ egi072

Goff F (1996) Vesicle cylinders in vapor-differentiated basalt flows. J Volcanol Geotherm Res 71:167-185. https://doi.org/10.1016/03770273(95)00073-9

Greenough JD, Lee CY, Fryer BJ (1999) Evidence for volatile-influenced differentiation in a layered alkali basalt flow, Penghu Islands, Taiwan. Bull Volcanol 60:412-424. https://doi.org/10.1007/ s004450050241

Hamilton CW, Glaze LS, James MR, Baloga SM (2013) Topographic and stochastic influences on pāhoehoe lava lobe emplacement. Bull Volcanol 75:1-16. https://doi.org/10.1007/s00445-013-0756-8

Harris AJL, Rowland SK (2009) Effusion rate controls on lava flow length and the role of heat loss: a review. Spec Publ IAVCEI 3351. https://doi.org/10.1144/IAVCE1002.3

Hartley ME, Thordarson T (2009) Melt segregations in a Columbia River Basalt lava flow: a possible mechanism for the formation of highly evolved mafic magmas. Lithos 112:434-446. https://doi.org/10. 1016/j.lithos.2009.04.003

Hon K, Kauhikau J, Denlinger R, Mackay K (1994) Emplacement and inflation of pāhoehoe sheet flows: observations and measurements of active lava flows on Kilauea Volcano, Hawaii. Geol Soc Am Bull 106:351-370. https://doi.org/10.1130/0016-7606(1994)106<0351: EAIOPS $>2.3 . \mathrm{CO} ; 2$

Jónsson J (1978) Geology of Reykjanes. Orkustofnun Jarðhitadeild 7831, 303 pp., Reykjavík

Kress VC, Carmichael ISE (1991) The compressibility of silicate liquids containing $\mathrm{Fe} 2 \mathrm{O} 3$ and the effect of composition, temperature, oxygen fugacity and pressure on their redox states. Contrib Mineral Petrol 108:82-92. https://doi.org/10.1007/BF00307328

Kuritani T, Yoshida T, Nagahashi Y (2010) Internal differentiation of Kutsugata lava flow from Rishiri Volcano, Japan: processes and timescales of segregation structures' formation. J Volcanol Geotherm Res 195:57-68. https://doi.org/10.1016/j.jvolgeores. 2010.06.003
Manga M, Stone HA (1994) Interactions between bubbles in magmas and lavas: effects of bubble deformation. J Volcanol Geotherm Res. https://doi.org/10.1016/0377-0273(94)90079-5

Marsh BD (2002) On bimodal differentiation by solidification front instability in basaltic magmas, part 1: Basic mechanics. Geochim Cosmochim Acta 66:2211-2229. https://doi.org/10.1016/S00167037(02)00905-5

Martin E, Sigmarsson O (2007) Low-pressure differentiation of tholeiitic lavas as recorded in segregation veins from Reykjanes (Iceland), Lanzarote (Canary Islands) and Masaya (Nicaragua). Contrib Mineral Petrol 154:559-573. https://doi.org/10.1007/s00410-0070209-5

Menand T (2011) Physical controls and depth of emplacement of igneous bodies: a review. Tectonophysics 500:11-19. https://doi.org/10. 1016/j.tecto.2009.10.016

Neave DA, Maclennan J, Thordarson T, Hartley ME (2015) The evolution and storage of primitive melts in the Eastern Volcanic Zone of Iceland: the $10 \mathrm{ka}$ Grímsvötn tephra series (i.e. the Saksunarvatn ash). Contrib Mineral Petrol 170:1-23. https://doi.org/10.1007/ s00410-015-1170-3

Parmigiani A, Faroughi S, Huber C et al (2016) Bubble accumulation and its role in the evolution of magma reservoirs in the upper crust. Nature 532:492-495. https://doi.org/10.1038/nature17401

Pedersen GBM, Höskuldsson A, Dürig T et al (2017) Lava field evolution and emplacement dynamics of the 2014-2015 basaltic fissure eruption at Holuhraun, Iceland. J Volcanol Geotherm Res 340:155-169. https://doi.org/10.1016/j.jvolgeores.2017.02.027

Philpotts AR, Carroll M, Hill JM (1996) Crystal-mush compaction and the origin of pegmatitic segregation sheets in a thick flood-basalt flow in the Mesozoic Hartford Basin, Connecticut. J Petrol 37: 811-836. https://doi.org/10.1093/petrology/37.4.811

Philpotts AR, Shi J, Brustman CM (1998) Role of plagioclase crystal chains in the differentiation of partly crystallized basaltic magma. Nature 395:343-346. https://doi.org/10.1038/26404

Pistone M, Arzilli F, Dobson KJ et al (2015) Gas-driven filter pressing in magmas: insights into in-situ melt segregation from crystal mushes. Geology 43:699-702. https://doi.org/10.1130/G36766.1

Rayleigh JWS (1896) Theoretical considerations respecting the separation of gases by diffusion and similar processes. Philos Mag 42:493498

Rogan W, Blake S, Smith I (1996) In situ chemical fractionation in thin basaltic lava flows: examples from the Auckland volcanic field, New Zealand, and a general physical model. J Volcanol Geotherm Res 74:89-99. https://doi.org/10.1016/S0377-0273(96)00059-5

Rossi MJ (1997) Morphology of the 1984 open-channel lava flow at Krafla volcano, northern Iceland. Geomorphology 20:95-112. https://doi.org/10.1016/S0169-555X(97)00007-X

Saemundsson K, Jóhannesson H, Hjartarson Á et al (2010) Geological map of Southwest Iceland. Iceland Geosurvey 1:100000

Self S, Thordarson T, Keszthelyi L et al (1996) Inflated pāhoehoe lava flow fields. Am Geophys Union 23:2689-2692. https://doi.org/10. 1029/96GL02450

Self S, Keszthelyi L, Thordarson T (1998) The importance of pāhoehoe. Annu Rev Earth Planet Sci 26:81-110. https://doi.org/10.1146/ annurev.earth.26.1.81

Sigmarsson O, Thordarson T, Jakobsson SP (2009) Segregations in Surtsey lavas (Iceland) reveal extreme magma differentiation during late stage flow emplacement. Spec Publ IAVCEI 85-104. https:// doi.org/10.1144/IAVCE1002.5

Sinton J, Grönvold K, Saemundsson K et al (2005) Postglacial eruptive history of the Western Volcanic Zone, Iceland. Geochem Geophys Geosyst 6:12. https://doi.org/10.1029/2005GC001021

Sisson TW, Bacon CR (1999) Gas-driven filter pressing in magmas. Geology 27:613-616. https://doi.org/10.1130/0091-7613(1999) 027<0613:GDFPIM>2.3.CO 
Sparks RSJ, Huppert HE, Turner JS et al (1984) The fluid dynamics of evolving magma chambers. Philos Trans R Soc Lond 310:511-534. https://doi.org/10.1098/rspa.1955.0102

Stephenson PJ, Zhang M, Spry M (2000) Fractionation modelling of segregations in the Toomba Basalt, north Queensland. Aust J Earth Sci 47:291-300. https://doi.org/10.1046/j.1440-0952.2000.00780.x

Thomson A, Maclennan J (2013) The distribution of olivine compositions in Icelandic basalts and picrites. J Petrol 54:745-768. https:// doi.org/10.1093/petrology/egs083

Thordarson T, Höskuldsson A (2008) Postglacial volcanism in Iceland. Jökull 58:197-228

Thordarson T, Larsen G (2007) Volcanism in Iceland in historical time: volcano types, eruption styles and eruptive history. J Geodyn 43: 118-152. https://doi.org/10.1016/j.jog.2006.09.005

Thordarson T, Self S (1998) The Roza Member, Columbia River Basalt Group: a gigantic pāhoehoe lava flow field formed by endogenous processes? J Geophys Res 103:411-438. https://doi.org/10.1029/ 98JB01355

Walker GPL (1987) Pipe vesicles in Hawaiian basaltic lavas: their origin and potential as paleoslope indicators. Geology 15:84-87. https:// doi.org/10.1130/0091-7613(1987)15<84:PVIHBL >2.0.CO;2

Walker GPL (1991) Structure, and origin by injection of lava under surface crust, of tumuli, "lava rises", "lava-rise pits", and "lava-inflation clefts" in Hawaii. Bull Volcanol 53:546-558. https://doi.org/10. 1007/BF00298155

White CM (2007) The graveyard point intrusion: an example of extreme differentiation of snake river plain basalt in a shallow crustal pluton. J Petrol 48:303-325. https://doi.org/10.1093/petrology/egl062

Wilson M (1993) Magmatic differentiation. Geol Soc Lond Mem 16: 205-218. https://doi.org/10.1144/gsigs.150.4.0611

Zavala K, Leitch AM, Fisher GW (2011) Silicic segregations of the Ferrar Dolerite sills, Antarctica. J Petrol 52:1927-1964. https://doi.org/10. 1093/petrology/egr035 